\title{
Notice of a new oxy-hydrogen blowpipe apparatus
}

\section{J.O.N. Rutter}

To cite this article: J.O.N. Rutter (1832) Notice of a new oxy-hydrogen blowpipe apparatus, Philosophical Magazine Series 3, 1:6, 470-471, DOI: 10.1080/14786443208647946

To link to this article: http://dx.doi.org/10.1080/14786443208647946

册 Published online: 01 Jun 2009.

Submit your article to this journal $\pi$

Џ Article views: 3

Q View related articles $₫$ 
the granite and slates; their contents, however, varying in the different rocks.

Being myself confined by circumstances to a district of primary rocks, I beg permission, through the pages of your Journal, to inquire whether any of your geological readers have ever traced the same vein from a primary into a secondary rock? If so, what were the attendant phænomena? Were the contents identical in both formations? Or do the veins which traverse each of these different formations, respectively terminate when falling in contact with rocks of the other series?

In the present imperfect state of our knowledge of the phænomena of metalliferous veins, any information connected with the subject of this inquiry cannot fail to be highly interesting; and it strikes me, that the intelligent agents of the lead mines in North Wales might supply some valuable matter.

Tavistock, September 19th, 1832.

I remain, \&c.

W. J. H.

\section{NOTICE OF A NEW OXY-HYDROGEN BLOWPIPE APPARATUS. BY}

\section{J. O. N, RUTITR.}

1 have caused to be constructed by Messrs. W. and S. Jones, 30, Holborn, an apparatus which is more simple, and at the same time more effective than either Clarke's or Gurney's blowpipe ; and it possesses the additional advantage of being perfectly safe. The most timid may use this instrument without the slightest danger of explosion. With ordinary precautions such an occurrence is absolutely impossible.

In Clarke's and Gurney's blowpipes it is well known that the gases are mixed in their due proportions previously to changing the respective reservoirs. In this consists their principal cause of insecurity,-to obviate which I condense the gases in separate vessels, and they are not mixed until in a state of combustion.

Excepting that the vessels I employ are larger than ordinary, I may describe my apparatus as consisting of two of Clarke's blowpipes, fixed parallel to each other on a mahogany slab, the jets being inclined so as to form an angle of about $5^{\circ}$, and separated by a partition $\frac{2}{5 \sigma}$ th of an inch thick. The orifices of the jets are considerably larger than those commonly used.

The dimensions of the vessels are as follows:- That for hydrogen (marked Hyo.), 10 inches long by 5 wide, and 4 deep; that for oxygen (marked Oxy.), of half the capacity of the former, viz. 10 inches long, $2 \frac{1}{2}$ wide, and 4 deep. It is important that the copper vessels be made very strong: this is the greatest difficulty I have had to contend with. With a 9-inch syringe I can condense from 800 to 1000 cubic inches of hydrogen gas into the largest vessel, and about half that quantity of oxygen into the vessel appropriated for it. That there can be no necessity for safety-valves, safety-tubes, wire-gauze, water, or oil, or mercurial chambers, must be apparent to every one whom the present communication may concern: these are consequently dispensed with. The tubes which conduct the gas from the respective vessels have each two stop-cocks to 
regulate the escape. A very little practice enables the operator to determine the quantity so as to produce the maximum of heat.

The usual experiments as performed by the apparatus I have thus, I fear, imperfectly described, are, if I may be allowed the use of the expression, infinitely more splendid and more impressive than can be effected by any other means with which I am acquainted. The lime experiment, especially, is inconceivably brilliant, exhibiting a disc of pure white light $1 \frac{1}{2}$ inch in diameter. With a piece of clock-spring I have filled an area of 3 feet diameter with the most beautiful coruscations.

The advantage of this apparatus is that of sufficient capacity that one or two charges will be sufficient for a course of illustrative experiments in a lecture-room. There is not the slightest danger of explosion. It is more powerful and more striking in its effects than any other instrument.

I shall have great pleasure in furnishing any further details that may be required.-Might not vessels of sufficient strength and capacity be constructed in which a store of gas could be kept at the most important light-houses, to be used in thick weather, in furtherance of Lieut. Drummond's plan?

Dr. Faraday has informed me that about the time that Clarke"s blowpipe was invented, an instrument somewhat similar to mine was shown him, and was, he believes, described in the Phil. Mag. But that instrument consisted of one vessel only, divided by a diaphragm. Hence there was no security against an explosive mixture forming in either of the chambers through a defect in the metal. Lymington, Hants, Sept. 10, 1832.

\section{NOTICE OF A MARINE DEPOSIT IN THE CLIFFS NEAR FAL- MOU'TH. BY R. W. FOX.}

Many persons are no doubt aware, that in some parts of the cliffs between Falmouth and Helford harbours, there exists an horizontal bed of rolled quartz pebbles, gravel and sand, similar in every respect to the materials which prevail on the contiguous sea-shore. Hence it cannot be questioned that the origin of both is the same; and I think it may also be assumed, from the above-mentioned materials being in many parts arranged in separate layers in the bed, that the sea must have frequently risen to its level.

The thickness of the bed varies from one to three feet and upwards, and it is situated generally about nine to twelve feet above the level of the highest spring tides. I have not yet extended my observations on this bed beyond about four miles of coast, but within these limits it seenss almost everywhere to exist when the cliffs are not composed of solid rock. This bed does not appear to penetrate far into the cliff, if we may judge from the few parts where it has been broken away or cut through. In one place I have observed it about eight feet, and in another twenty, within the face of the cliff. The rocks on this coast are of clay-slate, having a very considerable underlie, mostly towards the S.E.; but the bed in question is found only in those parts of the cliff which are composed of earth, stones, and de- 